Errata エラータ

\title{
Correction and Apology 訂正とお詫び
}

There was an error in Vol. 39 No. 3 (issued January 11, 2020). It has been corrected as follows.

本誌 Vol. 39 No. 3 （2020 年 1 月 11 日発行）に誤りがありました。下記のとおり訂正させていただきます。

Customer Retention Activities Using loT Data: The Case of “@Remote” by Ricoh

Hisashi Kawamata, Takeshi Moriguchi

IoT データを利用した顧客維持活動 ーリコー @Remote の事例 — 河股 久司, 守口 剛

\begin{tabular}{|l|l|l|}
\hline \multicolumn{1}{|c|}{$\begin{array}{c}\text { Correction } \\
\text { 訂正箇所 }\end{array}$} & \multicolumn{1}{|c|}{$\begin{array}{c}\text { Error } \\
\text { 誤 }\end{array}$} & \multicolumn{1}{c|}{$\begin{array}{c}\text { Correction } \\
\text { 正 }\end{array}$} \\
\hline $\begin{array}{l}\text { p. } 136 \\
\begin{array}{l}\text { Author Profile } \\
\text { 著者プロフィール }\end{array}\end{array}$ & 2018 年早稲田大学大学院商学研究科修了。 & $\begin{array}{l}2018 \text { 年早稲田大学大学院商学研究科修士課程 } \\
\text { 修了。 }\end{array}$ \\
\hline
\end{tabular}

